Litteratur

1. Skeie I, Clausen T, Bukten A. Legemiddelassistert rehabilitering - viktig behandling med dilemmaer. Tidsskr Nor Legeforen 2014: 134: 1156-8.

2. Clausen T, Åsland R, Kristensen O. Pasienter som avbryter LAR-behandling hvordan går det med dem? Tidsskr Nor Legeforen 2014; 134: 1146-9

\section{Re: Nekrose i fingre og tær etter lokalbedøvelse med adrenalin - en vandrehistorie?}

Dette var en flott oversiktsartikkel (1). Jeg har advokert for at lokalbedøvelse med adrenalin ikke gir risiko for nekrose i fingre og tær ovenfor andre avdelinger og sykehus i flere år. Håndkirurgi i lokalbedøvelse med adrenalin har vært praktisert ved plastikkirugisk avdeling på Haukeland universitetssjukehus i årevis uten at det er dokumentert noen skadelige effekter.

\section{Henrik Løvendahl Svendsen}

hlsvendsen@gmail.com

Henrik Løvendahl Svendsen (f. 1978) er lege i spesialisering ved Haraldsplass Diakonale Sykehus.

Ingen oppgitte interessekonflikter.

\author{
Litteratur \\ 1. Finsen V. Nekrose i fingre og tær etter lokalbedøvelse med adrenalin - en vandre- \\ historie? Tidsskr Nor Legeforen 2013; 133: 1827-30.
}

\section{Re: Om kvalitetsarbeid}

Dette er en viktig og god leder om forbedringsarbeid (1)! Det er et tankekors at system og prosessforbedring - basert på Demings Plan-Do-Study-Act (PDSA-sirkelen) - ikke har fått større plass enn det har i norsk helsevesen, selv om den nasjonale pasientsikkerhetskampanjen er et viktig unntak. Legeforeningens innsats kan gjøre en forskjell, først og fremst ved full mobilisering av relevante fagmedisinske foreninger, slik Legeforeningen gjorde da den organiserte de såkalte «Gjennombruddsprosjektene» (2). Kunnskapen som skal til for å drive moderne forbedringsarbeid er ikke spesielt vanskelig, men den må læres! Det «skader» ikke å ha god forskningskompetanse, men moderne system- og prosessforbedring krever en annen kompetanse, som de fleste av oss ikke har blitt eksponert for i de tradisjonelle utdanningsløpene. De fagmedisinske foreningene kan gjøre en forskjell - om de ikke allerede er på banen. Det er ingen tid å miste. Sett i gang. Alle må med!

\section{Hans Asbjørn Holm}

asbjholm@online.no

Hans Asbjørn Holm (f. 1941) er pensjonert lege, spesialist i indremedisin og tidligere fagdirektør i Legeforeningen.

Ingen oppgitte interessekonflikter.

\footnotetext{
Litteratur

1. Gjessing H. Om kvalitetsarbeid. Tidsskr Nor Legeforen 2014; 134: 1199.

2. Legeforeningen. Gjennombruddsprosjekter. https://legeforeningen.no/ Fag-og-fagutvikling/gjennombruddsprosjekter/ (29.6.2014)
}

\section{Re: Spasmer i beina - skade i nakken}

Denne interessante kasuistikken om nakkeskade (1) blir dessverre skjemmet av et uheldig figurvalg. MR-bildet som forfatterne har valgt er et T1-vektet bilde hvor man knapt kan ane spinalkanalen, og i hvert fall ikke se noen medullakompresjon. Hadde et T2-vektet bilde blitt valgt, ville informasjonsverdien vært betydelig større.
Det er uheldig at forfatterne ikke konsulterer radiolog i sitt arbeid med et slikt manuskript, og det er underlig at dette slipper gjennom Tidsskriftets redaksjonelle behandling. En annen ting er at myelopati for de fleste er en klinisk diagnose og ikke et MR-funn. MR kan vise medullakompresjon og medullaødem, men ikke myelopati.

Kjell Arne Kvistad

kjell.arne.kvistad@gmail.com

Kjell Arne Kvistad (f. 1960) er seksjonsoverlege på St Olavs hospital. Ingen oppgitte interessekonflikter.

\section{Litteratur}

1. Gjerde IO, Biørk MH. Spasmer i beina - skade i nakken. Tidsskr Nor Legeforen 2014: 134: 1150 .

\section{M.H. Bjørk \& I.O. Gjerde svarer:}

Kjell Arne Kvistad har rett $i$ at et T2 vektet bilde antagelig ville ha vist medullakompresjon bedre. Vi er også enige i at myelopati er en klinisk diagnose. Vår hensikt med kasuistikken var nettopp å vise et sjeldent, men viktig klinisk funn ved myelopati. Som pasienthistorien viser, er det vesentlig at leger kjenner til kliniske tegn ved skade eller sykdom i ryggmargen. Vi håper dette poenget kommer fram i kasuistikken på tross av suboptimal bildekvalitet.

\section{Marte Helene Bjørk \\ marte.bjork@k1.uib.no \\ Ivar Otto Gjerde}

Marte Helene Bjørk (f. 1980) er PhD og lege i spesialisering ved Nevrologisk avdeling, Haukeland universitetssykehus og postdoktor ved Universitetet i Bergen.

Ingen oppgitte interessekonflikter.

Ivar Otto Gjerde (f. 1947) er spesialist i nevrologi og i klinisk nevrofysiologi og er overlege på Nevrologisk avdeling, Haukeland universitetssykehus. Ingen oppgitte interessekonflikter.

\section{Re: Ytringsfrihed burde funnet Sted}

Dette var en svært velskrevet kronikk (1). Jeg er enig med forfatteren $\mathrm{i}$ at begrensninger i ytringsfriheten i praksis har blitt et stadig større samfunnsproblem gjennom de siste årene.

Jeg har flere ganger lest den korte romanen «Animal Farm» av George Orwell. Det er tankevekkende og trist å konstatere at stadig mer fra den romanen stemmer overens med virkeligheten, at det i vårt samfunn har vært en snikende utvikling der det i små steg blir stadig mindre ekte demokrati og stadig flere totalitære, Sovjetlignende tendenser.

Det viktigste er lojalitet mot systemet. Mindre viktig er hva som er best for pasientene, best for samfunnet, best for folk flest. Det er trist at det stadig blir gjort mer bruk av pervertert og misvisende statistikk og tallmagi, og at slikt i stadig større grad brukes for å tildekke sannheten og rettferdiggjøre bruk at Sovjet-lignende og/eller inkompetente ledelsesformer.

Samtidig er det godt å se at det finnes mange velfungerende arbeidsplasser, også i helsevesenet. Det finnes mange kompetente, samvittighetsfulle, varme ledere rundt omkring, folk som bidrar til mye bra for medarbeidere og pasienter.

Jeg håper at det etter hvert vil bli en kursendring i samfunnet og en holdningsendring i befolkningen, slik at det vil bli stadig flere ledere, arbeidsplasser og avdelinger som preges av en sunn og demokratisk kultur.

\section{Dan Ejstrup-Andersen}

dan@ejstrup.dk

Dan Ejstrup-Andersen (f. 1977) er psykologspesialist.

Ingen oppgitte interessekonflikter. 